\title{
GB03
}

\section{Correlation of Basic Unconformities in Sedimentary Cover Offshore Eastern Arctic}

\section{N.A. Petrovskaya* (Dalmorneftegeophysica) \& M.A. Savishkina (Dalmorneftegeophysica JSC)}

\section{SUMMARY}

Based on new seismic data acquired by Dalmorneftegeophysica JSC in 2010-2012 (Seismic Survey DRS CDP 108*, Gravity Survey, Magnetic Survey), an alternate interregional correlation scheme of basic unconformities was proposed and the age of sedimentary cover in the Chukchi, Easter-Siberian and Laptev Seas was proved. The delivered results give evidence of Late- Palaeozoic-Cenozoic age of the North Chukchi basin and Aptian-Cenozoic age of the Laptev Sea and Novosibirsk basins. 


\section{Корреляция основных несогласий в осадочном чехле шельфа Восточной Арктики}

\section{Петровская Н.А., Савишкина М.А. (ОАО «Дальморнефтегеофизика»)}

\section{Введение}

Представлена схема межрегиональной корреляции основных несогласий в осадочном чехле шельфа Восточной Арктики. Необходимость проведения исследований обусловлена отсутствием единой общепринятой схемы стратиграфической привязки сейсмических горизонтов (несогласий) в осадочном чехле бассейнов шельфа морей Лаптевых, ВосточноСибирского и Чукотского. Для создания схемы использована сейсмическая база данных (СР МОВ ОГТ 60-108*), представленная материалами, ОАО ДМНГ, выполненными в 1990-1991 и 2010-2012 гг. за счет различных источников финансирования.

\section{Основные несогласия}

Основой межрегиональной корреляции несогласий и соответствующих им сейсмическим горизонтам (с.г.) явились данные по скважинам Чукотского моря и Северного склона Аляски [4]. При определении возраста осадочного чехла учитывались сведения о геологическом строении и этапах развития региона, анализировались схемы стратификации, разработанные в последние годы различными организациями и авторами $[1,3]$.

В осадочном чехле бассейнов, по аналогии с американской частью Чукотского моря, выделены карбон-среднепермский (нижнеэлсмирский), (верхнеэлсмирский), верхнеюрско-барремский (рифтовый), апт-верхнемеловой (нижнебрукский) и кайнозойский (верхнебрукский) сейсмокомплексы.

Бассейны шельфа Восточной Арктики различаются стратиграфическим диапазоном, формационным составом и мощностью осадочного чехла. Северо-Чукотский бассейн выполнен позднепалеозой-кайнозойскими отложениями мощностью $20-24$ км. Лаптевоморском, Новосибирском и Лонгско-Чукотском бассейнах мощность апткайнозойского осадочного чехла достигает 20,15 и 4.5 км соответственно.

Для обозначения несогласий в бассейнах Восточно-Сибирского и Чукотского морей принята аббревиатура ДМНГ, означающая принадлежность к организации и номер с.г.( Рис. 1). Шести горизонтам присвоены дополнительные индексы, принятые в американской части шельфа. В Лаптевоморском бассейне горизонтам присвоен индекс, сочетающий название объекта (ARS) и номер горизонта (Рис. 1).

Карбон-среднепермский (нижнеэлсмирский) комплекс $\left(\mathrm{C}_{1}-\mathrm{P}_{2}\right)$ ограничен в кровле с.г. ДМНГ-16 (PU), фиксирующим региональное несогласие, обусловленное низким стоянием уровня моря на границе средней и поздней перми (260 млн. лет назад).

Верхнепермско-среднеюрский (верхнеэлсмирский) комплекс $\left(\mathrm{P}_{3}-\mathrm{J}_{2}\right)$ контролируется в кровле несогласием ДМНГ-14 (JU), формирование которого связано с орогенезом на границе средней и поздней юры. В конце средней юры (162 млн. лет) произошло понижение уровня Мирового океана. С этими событиями связано выведение побережья Чукотки из-под уровня моря отложения средней юры здесь не известны. В глубоких скважинах на шельфе Чукотского моря верхнеэлсмирский комплекс частично эродирован.

Верхнеюрско-барремский (рифтовый) комплекс ( $\left.\mathrm{J}_{3}-\mathrm{K}_{1} \mathrm{br}\right)$ ограничен в кровле несогласием ДМНГ-12 (BU), которое фиксирует завершение брукско-чукотской орогении, полностью преобразовавшей тектонический облик Чукотки, северной Аляски и шельф Чукотского моря. Главный этап становления орогена происходил 132-115 млн. лет назад [2]. 


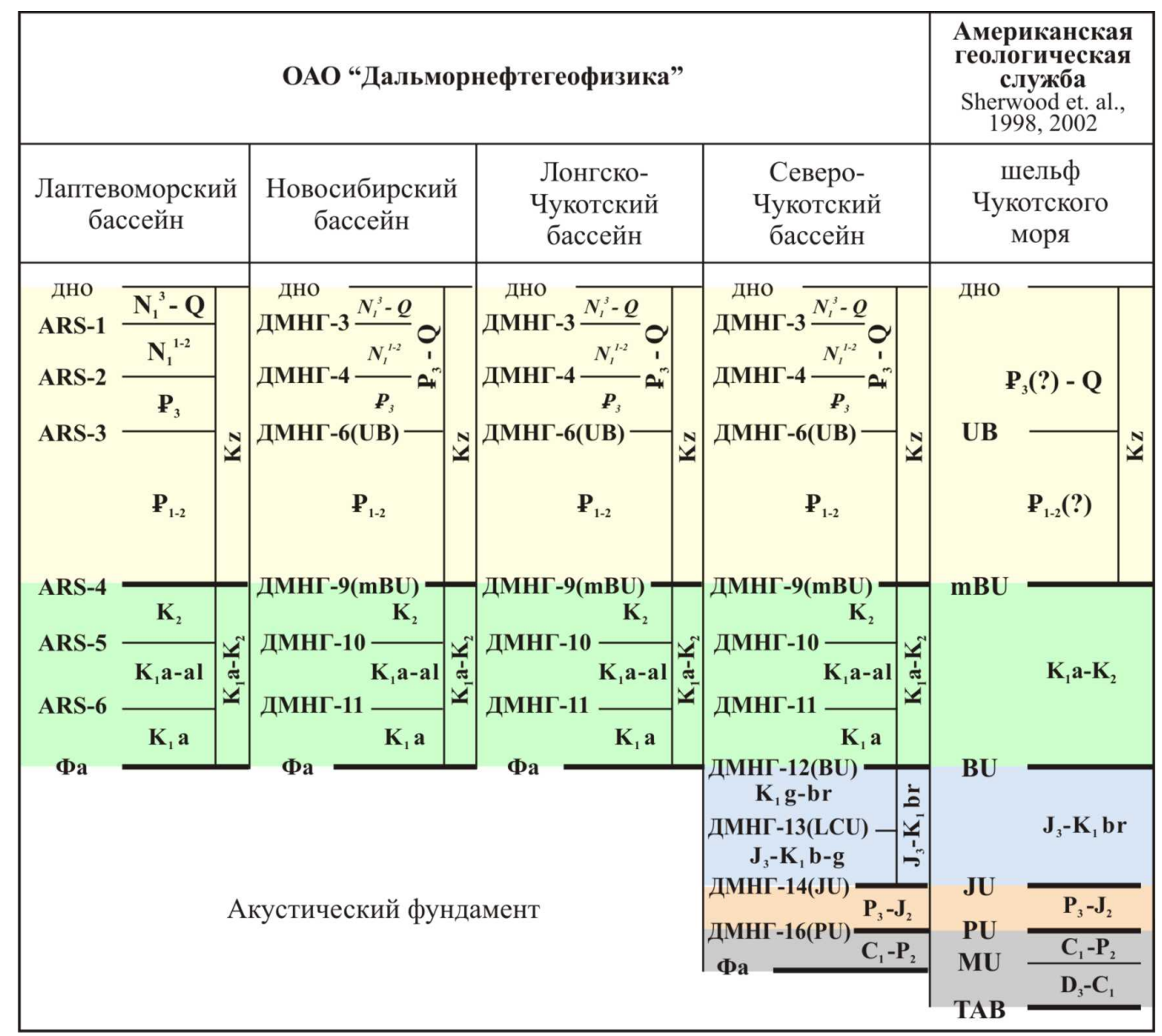

Рисунок 1 Корреляция сейсмических горизонтов Восточно-Арктического шельфа.

Апт-верхнемеловой (нижнебрукский) комплекс $\left(\mathrm{K}_{1} \mathrm{a}-\mathrm{K}_{2}\right)$ в кровле ограничен с.г. ДМНГ-9 $(\mathrm{mBU})$. Яркий сейсмический облик и эрозионный срез в кровле позволяют уверенно проследить его на шельфе Восточной Арктики и сопоставить с несогласием $\mathrm{mBU}$ в американской части Чукотского моря. Отличительным признаком является нарушенность постседиментационными сбросами и сбросо-сдвигами, а также наличие в прикровельной части комплекса пачки высокоамплитудных отражений с субпараллельным или шероховатым рисунком наслоения, указывающим на её формирование в условиях низкого стояния уровня моря. Такими же волновыми характеристиками обладает с.г. ARS-4 в Лаптевоморском бассейне.

\section{Литература}

1. Виноградов В.А., Горячев Ю.В., Гусев Е.А., Супруненко О.И. Осадочный чехол ВосточноАрктического шельфа России и условия его формирования в системе материк-океан. - 60 лет в Арктике, Антарктике и Мировом океане (под ред. В.Л. Иванова). СПб.: ВНИИОкеанология, 2008. C. 63-78.

2. Хаин В.Е., Филатова Н.И., Полякова И.Д. Тектоника, геодинамика и перспективы нефтегазоносности Восточно-Арктических морей и их континентального обрамления. М.: Наука, 2009. 227 с.

3. Шкарубо С.И., Заварзина Г.А. Стратиграфия и характеристика сейсмических комплексов осадочного чехла западной части моря Лаптевых // Нефтегазовая геология. Теория и практика. 2011. T. 6, №2. http://www.ngtp.ru/rub/2/14_2011.pdf.

4. Sherwood K.W. Revised version (04.2009) of correlation panel (available from kirk.sherwood@mms.gov),2009. 